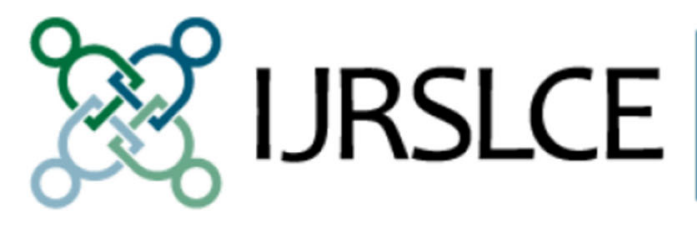

International Journal

for Research on

Service-Learning \&

Community Engagement

\title{
STEM and Service-Learning: Does Service-Learning Increase STEM Literacy?
}

\section{Barbara Hayford}

\section{Sally Blomstorm, Buffany DeBoer}

This article was originally published at:

https://journals.sfu.ca/iarslce/index.php/journal/article/view/61/23

Recommended Citation

Hayford, B., Blomstorm, S., \& DeBoer, B. (2014). STEM and service-learning: Does servicelearning increase STEM literacy?. International Journal of Research on Service-Learning and Community Engagement, 2(1). 32-43. 


\title{
STEM and Service-Learning: Does Service-Learning Increase STEM Literacy?
}

\author{
Barbara Hayford \\ Wayne State College \\ Sally Blomstrom \\ Embry-Riddle Aeronautical University \\ Buffany DeBoer \\ Wayne State College
}

\begin{abstract}
The importance of education in science, technology, engineering, and mathematics (STEM) disciplines is again a topic of discussion among policy makers and scientists, particularly given perceived declines in STEM performance by students in the U.S. Service-learning has been used in innovative and creative ways to enhance learning in a variety of STEM-related courses. Improving STEM literacy is also a focal point of STEM education and has been explicitly linked to servicelearning projects. Herein the authors review literature linking service-learning to academic achievement in STEM-related courses. They then examine whether service-learning enhances STEM literacy in a STEM-centered communications course at an aeronautics engineering university and in two biology courses at a small rural college. Despite early calls by researchers for improved rigor in the field of service-learning research, the literature review indicates that few studies over the past 15 years employed rigorous research techniques when examining whether service-learning affects academic achievement in STEM courses. Results of mixed-methods analyses showed that servicelearning enhanced science literacy in the three STEM-related courses. First, students scored significantly higher on a post-service survey of skills and content relative to the pre-survey survey at the aeronautics engineering university. Second, students earned significantly higher grades in a written report of their service-learning project relative to a non-service-oriented project in the small rural college. Third, students indicated through comments on evaluations and reflections that the service-learning projects enhanced the STEM content in the courses.
\end{abstract}

Keywords: service-learning; STEM education

The importance of education in science, technology, engineering, and mathematics (STEM) disciplines is again a topic of discussion among policy makers and scientists, with researchers focusing on how to incentivize education research on problems and practice and how to catalyze change in the ways educators teach science (Alberts, 2013). The renewed interest comes at a time when two thirds of American students who take the ACT score below benchmark values considered indicative of success in freshman-level college science classes (ACT, 2013). About 30\% of eighthgrade students in the U.S. test at below basic knowledge of science (Nation's Report Card, 2011). Service-learning has been used in innovative and creative ways to enhance STEM learning in a variety of STEM-related courses (e.g., Blomstrom, 2010; Ghosh-Dastidar \& Tsenova, 2012; Hamann \& Drossman, 2006; Kammler, Truong, VanNess, \& McGowin, 2012; Tedesco \& Salazar, 2006). Improving STEM literacy is also a focal point of STEM education (Krajcid \& Sutherland, 2010) and has been explicitly linked to service-learning projects (Reynolds \& Ahern-Dobson, 2010). Herein we examine the relationship between service-learning and STEM learning outcomes from the 
perspective of gains in STEM literacy. STEM literacy has been variously defined over the past several decades (Holbrook \& Rannikmae, 2009; Krajcik \& Sutherland, 2010; Laugksch, 2000; Norris \& Phillips, 2003; Organization for Economic and Cooperation and Development, 2007; Pearson, Moje, \& Greenleaf, 2010; Reynolds \& Ahern-Dobson, 2010; Yore \& Treagust, 2006). We use the fundamental and derived senses of STEM literacy as described by Norris and Phillips (2003). The fundamental sense refers to one's ability to read and/or write science text, tables, and graphics. The derived sense refers to one's education in science and his or her ability to apply scientific knowledge. We posit that STEM literacy can be enhanced by students' experiences in servicelearning projects and have designed a study to test this relationship. In an effort to respond to suggestions for high-quality research in service-learning (e.g., Eyler, 2002; Perry \& Imperial, 2001; Yorio \& Ye, 2012;), we first review the status of research on service-learning in STEM courses and then employ a mixed-methods analysis (i.e., one that employs qualitative and quantitative analytical methods) of literacy-based projects in three STEM courses at two different institutions of higher education.

\section{Learning Outcomes in STEM-Related Service-Learning Research}

The practice and pedagogy of service-learning have been studied for decades and recently have been institutionalized in a growing number of colleges and universities (Butin, 2006). The increased use of service-learning pedagogy at the post-secondary level has been accompanied by only a few largescale studies on the efficacy of integrating meaningful community service with instruction. Some large-scale studies done in the late 1990s and early 2000s showed positive impacts of servicelearning on academic performance (e.g., Astin, Vogelgesang, Ikeda, \& Yee, 2000; Eyler \& Giles, 1999; Perry \& Imperial, 2001). However, the paucity of rigorous research in service-learning, including studies relating practice to learning outcomes, was noted at the time by Eyler (2002). She called for improving research design by explicitly identifying independent variables and by taking more care in choosing dependent variables. Further, she suggested that researchers should form testable hypotheses and link their research to theory. Perry and Imperial (2001) also recognized that research on service educational projects can be improved through more quantitatively rigorous research. They based their findings on a massive database search of 2,558 studies published during the 1990s. They searched journal and periodical articles, dissertations and theses, book chapters, books, and reports. Their final analyses were based on 997 research-oriented studies pulled from the larger dataset. Only 34 of the 997 studies employed an experimental or quasi-experimental research design. Though a good deal has been learned about the psychological aspects of service, fragmentation and conflicting terminology serve as barriers to the development of theory.

Yorio and Ye's (2012) meta-analysis of service-learning research bracketed the early 1990s to 2000. Their research crossed disciplines, clearly identified dependent and independent variables, and tested hypotheses. They created a dataset composed of research-based service-learning articles published from 1993-2000 and initially found 200 research-based articles, of which only 40 had enough data for meta-analyses. They found that service-learning did have a positive and statistically significant impact on cognitive development but that the cognitive outcomes were significantly influenced by whether the researchers employed objective measures (i.e., GPA, exams, etc.) or subjective measures (i.e., self-reporting) (Yorio \& Ye, 2012). Yorio \& Ye (2012) make clear that despite recommendations by researchers (Eyler 2002; Perry \& Imperial, 2001), few studies on service-learning today involve rigorous research techniques, particularly in STEM courses. The focus of this paper lies in identifying ways to effectively measure learning outcomes in STEM-based, service-learning courses or in communication courses for STEM students. Felton and Clayton (2011) suggested that "[f]actual knowledge and lower level learning goals might not adequately capture service-learning's most significant contributions to students' academic development.... [O]n higher order thinking tasks, such as analytical essays and case-based assignments, students in 
service-learning sections consistently performed better than their peers" (pp. 79-80). One way to measure outcomes is through assessment of cognitive development, comprising "management skill development; writing skills; problem-solving skills; critical-thinking skills; GPA; course performance" (Yorio \& Ye, 2012, p. 11). Essays, presentations, research papers, and service-learning reflections can be measured as forms of science literacy, or, more inclusively, STEM literacy outcomes.

We explore the ways service-learning enhances STEM literacy in two college/university courses and in K-8 student service-learning project participants. To address the effect of institutional type on our research (e.g., limitations identified by Astin et al. 2000, p. 99), we demarcate the higher education continuum by studying STEM-related service-learning from an open-enrollment rural college and a private aeronautics engineering university. To address the effect of discipline and subdiscipline (e.g., limitations identified by Astin et al. 2000, p. 99), we have included longitudinal data from communications classes comprising students in physical STEM majors (i.e., space physics, meteorology, aviation, and engineering), longitudinal data from a general education environmental biology class, and one-time data from a majors biology research class. We have been unable to construct a true experimental design with randomly selected control groups, but we have employed quasi-experimental design, pre- and post-service self-evaluation, and both objective and subjective outcome data. Finally, we use the results of our study and a literature review of science literacy to propose a new science literacy tool for assessing cognitive development and service-learning outcomes.

\section{Methods}

\section{Application of Service-Learning Theory to the Described Projects}

Research on service-learning should be embedded within service-learning theory (Eyler, 2002; Kiely, 2005). Service-learning applications vary depending on the content area and the project; however, commonalities exist. Campus Compact (2011) states: "Service-learning incorporates community work into the curriculum, giving students real-world learning experiences that enhance their academic learning while providing a tangible benefit for the community" (para. 1). Learn and Serve America (2011) adds that service-learning "provides structured time for students to reflect on their service experiences and demonstrate knowledge or skills they have gained" (para. 1). Four major standards should be met to achieve quality service-learning: duration and intensity, links to curriculum, partnerships, and meaningful service (Billig \& Weah, 2008). To these, we would add reflection as a fifth standard due to the body of evidence indicating how integral reflection is for making connections between service and learning and its value in transformative experiences. (See Table 1). Herein we provide a partial review of the literature related to these five standards.

\section{Description of Service-Learning Projects}

\section{Embry-Riddle Aeronautics University}

Embry-Riddle Aeronautics University (ERAU) is a private institution focusing on education in engineering, aviation, and aeronautics including meteorology, space physics, aviation business, and global security. The service-learning projects took place on the Prescott Campus, a small, primarily undergraduate branch campus. Enrollment during the course of this study was approximately 1,800 students. Students come from 50 U.S. states and from several foreign countries, with international students comprising $4 \%$ of the student population. A total of 696 students were engaged in STEM 
Table 1. Principles of Effective Practice for Service-Learning Projects (modified from Billig \& Weah, 2008; Learn and Serve America, 2011)

\begin{tabular}{|c|c|}
\hline Principle & Supporting research \\
\hline Duration and Intensity & $\begin{array}{l}\text { Service-learning experiences that involved longer duration and more intensity resulted in } \\
\text { higher perceived value of the project and higher likelihood of committing to further } \\
\text { service (Eyler \& Giles, 1997). Kraft and Krug (1994) reported the desired outcomes were } \\
\text { found when students participated in } 6 \text { to } 8 \text { weeks of experience in service-learning with } \\
\text { field work once a week (p. 4). }\end{array}$ \\
\hline Links to Curriculum & $\begin{array}{l}\text { According to Eyler and Giles (1999), service and learning should have equal weight and } \\
\text { enhance each other. Research on CalServe indicated that academic effects were related to } \\
\text { clarity of goals and activities through focused reflection, which is an integral part of } \\
\text { service-learning (Ammon, Furco, Chi, \& Middaugh, 2002). Billig's (2000) review } \\
\text { showed that service-learning enhances acquisition of academic skills and knowledge in } \\
\text { K-12 students. }\end{array}$ \\
\hline Partnerships & $\begin{array}{l}\text { Billig (2002) noted that a key factor for sustainability of service-learning projects was a } \\
\text { reciprocal relationship with mutual high regard. Furco (2002) reported students formed } \\
\text { partnerships with community supervisors and also with other students and with faculty. }\end{array}$ \\
\hline Meaningful Service & $\begin{array}{l}\text { Service-learning projects have a positive influence on student's understanding of social } \\
\text { issues and significantly affected their personal insight (Yorio \& Ye 2012). Reflection is } \\
\text { an integral part of meaningful service. Kiely (2005) showed that service-learning is } \\
\text { transformative through crossing contextual borders, by producing dissonance, by } \\
\text { personalizing response to dissonance, by processing through reflective learning, and by } \\
\text { connecting from empathizing with participants and partners of the service-learning } \\
\text { venture. }\end{array}$ \\
\hline Reflection & $\begin{array}{l}\text { The reflection component of service-learning is critical. Eyler and Giles (1999) report } \\
\text { that reflection helps students gain a deeper understanding of what they learned. Ash and } \\
\text { Clayton (2009) suggest that students might be asked in a questionnaire to what degree } \\
\text { they think they have met the learning objectives of their applied learning experience. } \\
\text { Kiely (2005) showed that service-learning is transformative through crossing contextual } \\
\text { borders, by producing dissonance, by personalizing response to dissonance, by } \\
\text { processing through reflective learning, and by connecting from empathizing with } \\
\text { participants and partners of the service-learning venture. }\end{array}$ \\
\hline
\end{tabular}

service-learning projects from the fall of 2007 through the spring of 2013. The students worked in teams to develop and deliver presentations on STEM-related content. These projects were completed primarily with the Director of the NASA Educator Resource Center (ERC), who served as a community partner. The presentations were delivered live as online webinars and/or recorded as videos. Many presentations were delivered in more than one format. The audiences included area K8 classes, participants in the local after-school program, and students and teachers throughout the state. This project met each of the five standards for high-quality service-learning (Table 2). Quantitative data collected included subjective assessment of learning gathered from student skills surveys completed at the beginning and the end of the semester. The student skills survey explicitly examined the student's perceptions of their skills in five categories of STEM literacy: content, organization, delivery, team skills, and personal skills.

Qualitative data collected included reflective comments, course evaluations, and feedback from the Director of the NASA ERC, the director of the after-school program, teachers, and students. In almost every instance, the Director of the ERC met with students on at least two occasions, one of which was one week before their presentations. She provided feedback on their content, their visuals, and their delivery. She was also available by email and phone to answer any questions. 
Table 2. Application of Billig and Weah's (2008) and Learn and Serve America's (2011) Standards and Indicators for Quality Service-Learning to Courses in This Study

\begin{tabular}{|c|c|c|c|c|}
\hline $\begin{array}{l}\text { Duration and } \\
\text { Intensity }\end{array}$ & $\begin{array}{l}\text { Link to } \\
\text { Curriculum }\end{array}$ & Partnerships & Meaningful Service & Reflections \\
\hline $\begin{array}{l}\text { WSC- } \\
\text { Environmental } \\
\text { Concerns: } \\
\text { (Duration) the } \\
\text { service-learning } \\
\text { project took place } \\
\text { once a week over } \\
\text { the entire semester } \\
(\sim 14 \text { weeks). }\end{array}$ & $\begin{array}{l}\text { WSC- } \\
\text { Environmental } \\
\text { Concerns: Student } \\
\text { participation in the } \\
\text { project was linked } \\
\text { to their achieving } \\
\text { the course learning } \\
\text { objectives and to } \\
\text { the broader learning } \\
\text { objectives for } \\
\text { general education at } \\
\text { WSC. }\end{array}$ & $\begin{array}{l}\text { WSC-Environmental } \\
\text { Concerns: The WSC } \\
\text { campus community } \\
\text { served as partner and } \\
\text { included fellow } \\
\text { students, professors, } \\
\text { and staff so the } \\
\text { service-learning } \\
\text { participants were } \\
\text { closely tied to their } \\
\text { community partners. }\end{array}$ & $\begin{array}{l}\text { WSC-Environmental } \\
\text { Concerns: The } \\
\text { project had meaning } \\
\text { through meeting a } \\
\text { need to clean up the } \\
\text { environment on } \\
\text { campus while } \\
\text { simultaneously } \\
\text { teaching participants } \\
\text { and partners about } \\
\text { the value of } \\
\text { recycling. }\end{array}$ & $\begin{array}{l}\text { WSC- } \\
\text { Environmental } \\
\text { Concerns: } \\
\text { Students wrote } \\
\text { reflections and } \\
\text { provided formal } \\
\text { feedback on } \\
\text { their service- } \\
\text { learning project } \\
\text { through course } \\
\text { evaluations. }\end{array}$ \\
\hline $\begin{array}{l}\text { WSC- } \\
\text { Biomontoring: } \\
\text { (Duration) the } \\
\text { service-learning } \\
\text { project took place } \\
\text { once a week over } \\
\text { the entire semester } \\
(\sim 14 \text { weeks). }\end{array}$ & $\begin{array}{l}\text { WSC- } \\
\text { Biomontoring: } \\
\text { Student } \\
\text { participation in the } \\
\text { project was linked } \\
\text { to their achieving } \\
\text { the course learning } \\
\text { objectives and to } \\
\text { departmental } \\
\text { learning objectives } \\
\text { relating to inquiry, } \\
\text { laboratory, and field } \\
\text { experiences. }\end{array}$ & $\begin{array}{l}\text { WSC-Biomontoring: } \\
\text { the partner was the } \\
\text { Wayne Chapter of } \\
\text { the Izaak Walton } \\
\text { League (IKES). } \\
\text { Students worked } \\
\text { closely with } \\
\text { members of IKES in } \\
\text { their service. This } \\
\text { project linked partner } \\
\text { needs to needs of the } \\
\text { audience participants } \\
\text { from Wayne } \\
\text { Community Schools. }\end{array}$ & $\begin{array}{l}\text { WSC-Biomontoring: } \\
\text { The project had } \\
\text { meaning by } \\
\text { addressing the need } \\
\text { for increasing the } \\
\text { number of STEM- } \\
\text { based experiences for } \\
\text { K-12 students in the } \\
\text { region while also } \\
\text { monitoring an } \\
\text { imperiled ecosystem. } \\
\text { Teachers of the third } \\
\text { grade class have } \\
\text { asked to participate } \\
\text { in future project. }\end{array}$ & $\begin{array}{l}\text { WSC- } \\
\text { Biomontoring: } \\
\text { Students wrote } \\
\text { reflections and } \\
\text { provided formal } \\
\text { feedback on } \\
\text { their service- } \\
\text { learning project } \\
\text { through course } \\
\text { evaluations. }\end{array}$ \\
\hline $\begin{array}{l}\text { ERAU: (Duration) } \\
\text { the service- } \\
\text { learning project } \\
\text { took place over } 6 \\
\text { weeks during a } 16 \\
\text { week semester and } \\
\text { students worked to } \\
\text { prepare and deliver } \\
\text { presentations. } \\
\text { Between } 20 \text { and } \\
30 \% \text { of the course } \\
\text { grades were } \\
\text { determined by the } \\
\text { service-learning } \\
\text { project } \\
\text { participation. }\end{array}$ & $\begin{array}{l}\text { ERAU: Students } \\
\text { were achieving } \\
\text { specific learning } \\
\text { outcomes for the } \\
\text { course including } \\
\text { increasing their } \\
\text { abilities to speak } \\
\text { publicly and to } \\
\text { work in groups. } \\
\text { Outcomes were } \\
\text { aligned with the } \\
\text { university mission, } \\
\text { vision, and the } \\
\text { accrediting } \\
\text { agencies' } \\
\text { objectives. }\end{array}$ & $\begin{array}{l}\text { ERAU: Partners } \\
\text { included the NASA } \\
\text { Educator Resource } \\
\text { Center, an } \\
\text { afterschool program } \\
\text { called Kids \& } \\
\text { Company, and local } \\
\text { teachers. Partners } \\
\text { worked together over } \\
\text { time to improve the } \\
\text { project outcomes for } \\
\text { all participants. }\end{array}$ & $\begin{array}{l}\text { ERAU: This project } \\
\text { addressed the } \\
\text { problem of low } \\
\text { science scores in the } \\
\text { state of Arizona, } \\
\text { which were presented } \\
\text { to the ERAU } \\
\text { students. The ERAU } \\
\text { participants provided } \\
\text { science content and } \\
\text { also served as } \\
\text { excellent role } \\
\text { models, } \\
\text { communicating about } \\
\text { STEM topics in an } \\
\text { engaging and } \\
\text { interesting way. }\end{array}$ & $\begin{array}{l}\text { ERAU: Students } \\
\text { were required to } \\
\text { write reflections } \\
\text { relating to their } \\
\text { service-learning } \\
\text { experiences. }\end{array}$ \\
\hline
\end{tabular}

\section{Wayne State College}

Two service-learning projects were conducted at Wayne State College (WSC), a small regional, primarily undergraduate institution in northeastern Nebraska. Enrollment during the course of this study was approximately 3,400 students. Most WSC students are from rural areas in the region. 
Environmental Concerns recycling service-learning project. A total of 402 students were engaged in the Environmental Concerns recycling project from the fall of 2005 through the spring of 2009. This STEM service-learning project was similar to the ERAU service-learning projects described above in that it was long-term and produced science literacy outcomes. Students collected and cleaned recyclable products (i.e., plastic bottles and aluminum cans) from designated recycling bins around the WSC campus. The community partner was the WSC campus community, composed of faculty, staff, and students. The project met all five principles of effective service-learning (Tables 1 and 2). Quantitative data collected to assess the service-learning projects included subjective assessment of student learning gathered from service-learning surveys and an objective assessment of learning outcomes gathered from graded written reports/reflection pieces. Qualitative data collected included comments from reflections and course evaluations.

Biological seminar: Biomonitoring. A total of $13 \mathrm{WSC}$ students were engaged in the biomonitoring service-learning project during fall of 2008. This project was conducted during a onetime course involving biology majors. Students developed a service-learning project in which they designed and hosted an environmental monitoring event for area third-grade students. The community partner was the Wayne Izaak Walton League (IKES). The Wayne IKES Lake experienced a fish kill during the summer of 2008, and members wanted to assess the environmental condition of the lake. The biology students guided the third-graders in gathering environmental data on the lake (e.g., insect diversity, water quality), gathered the field data, and produced a report for the community partner. Based on their experience sampling the lake with the third-grade participants, they produced a written protocol for sampling environmental data that they presented to the IKES members. This project is similar to the ERAU service-learning project in that the college students needed to communicate environmental science to the young participants and thus had to bridge the divide between their science language and the home language accessible by the thirdgraders. The project met all five principles of effective service-learning (Tables 1 and 2). Quantitative data collected to assess the service-learning project included subjective assessment of student learning gathered from service-learning surveys. Qualitative data collected included comments from reflections, student course evaluations, and evaluation of participant feedback, including analysis of drawings produced by the third-grade students.

\section{Data Analysis}

\section{Embry-Riddle}

A mixed-methods, exploratory design was used to explore whether service-learning enhanced STEM literacy. Qualitative data included two reflective papers. Quantitative data included pre- and postservice responses to a student skills survey. The student skills survey was a self-report measure of content development, organization, delivery, personal skills, and team skills. Students received one to two points for completing the surveys (assigned points varied over the years of the study), and our best estimates indicate that about $63 \%$ of the students responded to the surveys. A subset of data was analyzed for the purpose of matching pre- and post-project surveys. A one-way analysis of variance (ANOVA) was used to test whether students self-reported gains in skills (as dependent variables) after participating in the science literacy-based STEM service-learning project (as the independent variable). Reflection was integrated into the course as an assignment resulting in $70 \%$ participation by the service-learning students. Prompting questions used to illicit comments from reflections yielded results indicating that the service-learning project was effective in facilitating increases in students' learning. Students articulated specific aspects of the learning they acquired through the service-learning project in terms of the five factors of the student skills survey. For the content factor, most of the comments related to the research done by students on their respective topics and indicate a stronger grasp of the STEM subject matters that they researched. The content factor also 
included comments related to selecting appropriate language and creating or using appropriate visuals. The organization factor was addressed through a large number of comments related to adapting the presentation to the audience. The delivery factor was addressed through comments related to delivering the presentation online (i.e., using a manuscript and not having audience involvement), delivering the presentation face-to-face (which most students preferred due to audience feedback), the anxiety experienced in both online and face-to-face delivery, and confidence in presenting. The team skills factor was addressed through comments related to the item "incorporate comments from critiques into the final presentation." Some students' comments for team skills related to time management. For personal skills, too few comments were made in the reflective comments to analyze.

\section{Wayne State}

A mixed-methods, exploratory design was used to explore whether service-learning enhanced STEM literacy. Subjective assessment of learning was analyzed by calculating percent and mode of responses to questions such as, "The service aspect of this course helped me to understand better the required lectures and readings." Objective assessment of learning for the recycling service-learning project was analyzed by assessing the grades from a formal written reflection. We hypothesized that students engaged in this service-learning project would perform better in the written reflection than those in a control group, which was composed of students in the same class who wrote a report and reflection piece for a project related to calculating their carbon footprint. This latter group was not randomly selected and thus represents a pseudo-control group. A one-way analysis of variance (ANOVA) was used to test for significant differences in grades between the test and control groups. A general linear model (GLM) ANOVA was used due to unequal sample size between the comparison groups. Surveys and reflections were integrated as assignments in class; therefore, response rates were high (98-100\%) for both the survey questions and participation in writing reflections and reports. Descriptive statistics were calculated using Microsoft Excel and ANOVA were run using Number Crunching Statistical Software ${ }^{\circledR}$, with significance set at $P \leq 0.05$.

\section{Results}

\section{Embry-Riddle}

Quantitative analyses indicate that the ERAU students' STEM literacy was enhanced by their service-learning project. Students scored significantly higher in the post-service student skills survey than on the pre-service surveys for all five literacy categories, indicating that they had improved both their STEM literacy skills through working on their service-learning projects (Table 3).

Table 3. Mean (and One Standard Deviation) Scores on the ERAU Pre- and Post-Project Survey

\begin{tabular}{|c|c|c|}
\hline Survey categories (ANOVA statistics) & Survey & $\begin{array}{l}\text { Mean, } \\
\text { Standard Deviation }\end{array}$ \\
\hline \multirow[t]{2}{*}{ Content $(\mathrm{F}=77.26, p \leq 0.00)$} & Pre-project & $3.60, \pm 0.55$ \\
\hline & Post-project & $4.27, \pm 0.55$ \\
\hline \multirow[t]{2}{*}{ Organization $(F=71.78, p \leq 0.00)$} & Pre-project & $3.37, \pm 0.69$ \\
\hline & Post-project & $4.14, \pm 0.64$ \\
\hline \multirow{2}{*}{ Delivery $(\mathrm{F}=60.89, \mathrm{p} \leq 0.00)$} & Pre-project & $3.24, \pm 0.83$ \\
\hline & Post-project & $4.06, \pm 0.69$ \\
\hline \multirow{2}{*}{ Team Skills $(F=24.96, p \leq 0.00)$} & Pre-project & $3.86, \pm 0.61$ \\
\hline & Post-project & $4.25,+0.54$ \\
\hline \multirow{2}{*}{ Personal Skills $(\mathrm{F}=23.14, \mathrm{p} \leq 0.00)$} & Pre-project & $4.13, \pm 0.52$ \\
\hline & Post-project & $4.45, \pm 0.46$ \\
\hline
\end{tabular}


Qualitative assessment of their reflection pieces confirms this result. The following comments exemplify the ways in which the project enhanced STEM literacy:

- "I now know that because Mercury has such a thin atmosphere and because it is mainly made up of carbon dioxide, it's not going to have weather systems. But more of the active atmospheres consist of gases like hydrogen and helium. I learned a lot about this topic through this project, I knew very little about it before starting research, so I basically started from scratch."

- "I gained information on my topic through the use of online sources. My main sources of information were NASA and National Geographic. I learned the most about types of satellite orbits and theories of moon formation. Presenting on the topic did cause me to get to know the subject matter better."

- "Presenting the topic allowed me to learn about it way more than I have ever had. I gained the information from research and learned just about everything that I presented."

- "My three main points were Jupiter's largest moons are the Galilean moons, the ring around Saturn has mysterious origins and is made of ice, and Titan is a very unique moon. Those points are part of what I learned from this project."

\section{Wayne State College}

Scores on the STEM literacy outcome (report/reflection piece) for the Environmental Concerns students were significantly higher for the service-learning recycling project than they were for the environmental footprint report (Figure 1), directly linking literacy to the service project. The overwhelming majority of the biomonitoring students indicated that their learning was enhanced by their participation in the service-learning projects (Figure 2). The entire biomonitoring class was centered on literacy outcomes (e.g., protocol, demonstrations for students); thus, their subjective assessment of learning not only content but also STEM communication skills through the servicelearning project indicates that their STEM literacy was enhanced through the project.

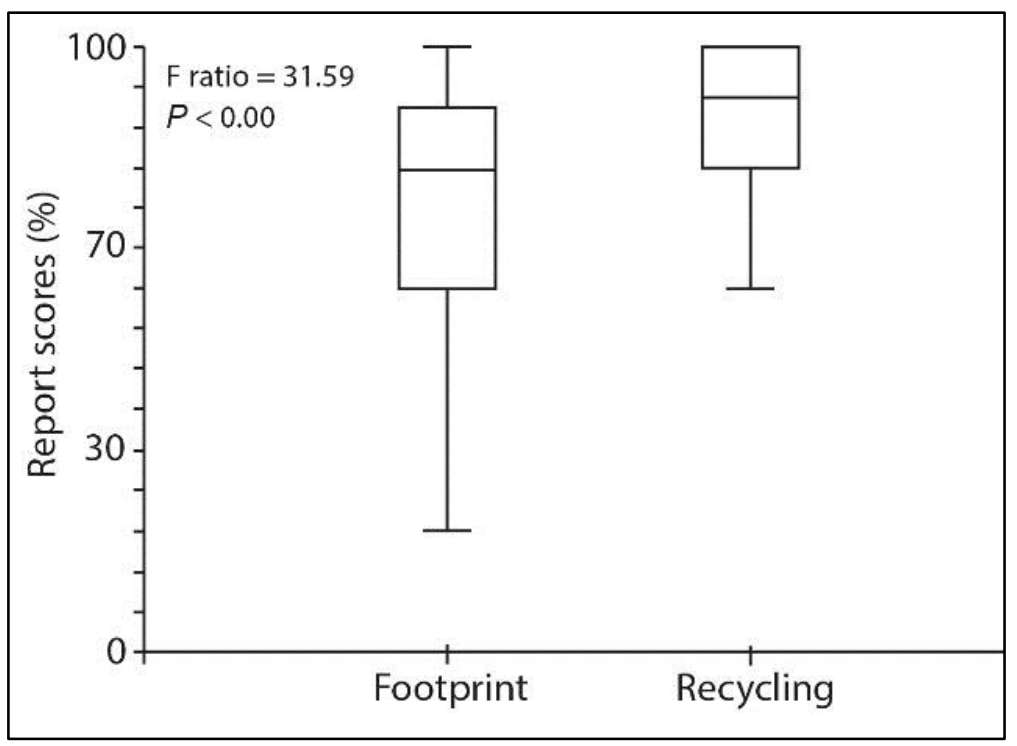

Figure 1. Percent scores on student reports on a service-learning recycling project and a non-servicelearning environmental project. 


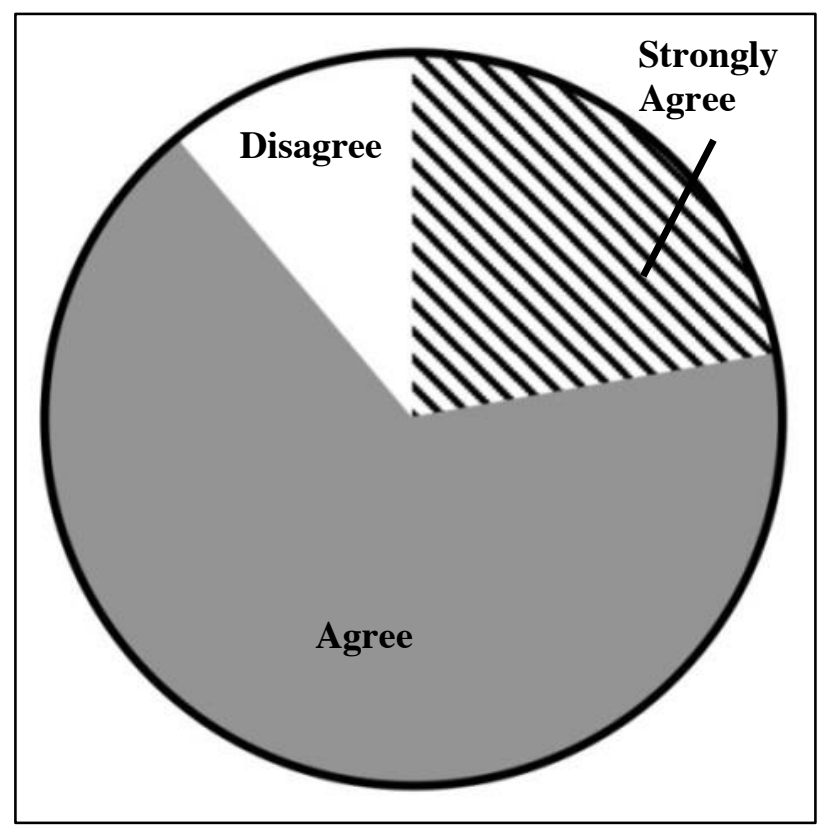

Figure 2. Pie chart indicating whether student learning was enhanced by the service-learning project in the WSC biomonitoring course. Data is based on self-evaluation of learning in response to the question, "The service aspect of this course helped me to understand better the required lectures and readings."

Qualitative assessment of Environmental Concerns students' reflection pieces confirms this result as well. Students clearly valued their service-learning experiences, with $90 \%$ of the 402 participants providing positive comments about the project. Examples of reflection comments include:

- "Recycling made the environment seem more personal."

- "The hands on recycling was a great experience."

- "The recycling project is very rewarding."

- "The recycling lab was a very strong learning method."

- "The book was a waste of money. I like the recycling."

- "I really enjoyed doing all the recycling on campus! It has helped me at home to start recycling as well."

- "Recycling helped to drive home the information we were learning in class."

Results were mixed for the students in the majors biomonitoring class. Nine out of 13 students made comments of which six were favorable, including comments like these:

- "[I] liked the service learning."

- "This class really taught me a lot about real life and what I want to do when I become a biologist. I loved going to IKES lake."

- "Creating and presenting [the] protocol made us be just as accountable for the [course] information plus is more applicable to real life."

- "I learned a lot, and had a lot of fun." 


\section{Limitations and Discussion}

The three projects were assessed using different methods, each with its strengths and limitations. STEM literacy was more directly measured in the ERAU project partly because the project was focused on STEM communications and partly due to the use of the pre- and post-service surveys. However, the surveys were based on subjective assessment. We feel that an appropriate STEM literacy tool and rubric would allow for more direct, objective assessment of service-learning on STEM literacy. The reflective comments yielded results indicative of the effect the service-learning project had on learning. Although the reflection pieces produced valuable qualitative data, we feel that the directed nature of the reflective comments may yield more data for analysis with modifications. Subjective assessment also indicated that students learned content material through their service-learning experiences in the biomonitoring class, but no objective assessment grading rubrics were used to examine the various STEM literacy outcomes. Since the learning outcomes for the entire class were literacy projects (i.e., protocols and demonstrations), we infer that the servicelearning project enhanced STEM literacy, but we have no direct data. We do have robust quantitative data for the Environmental Concerns objective assessment of learning outcomes - the grades for the reflection/report assignment. However, we do not have grades for individual literacy components for the assignment and thus cannot examine the relationship among the service-learning, knowledge, reading, writing, and application. The qualitative data for the WSC projects can be greatly improved by employing directed questions such as those used for the ERAU projects. Finally, reflection questions and prompts were different between the two schools, again indicating a need for some sort of common literacy assessment tool for use in future research.

Both objective and subjective assessment indicated that student STEM literacy was enhanced by service-learning projects. Reflections also showed that students learned from and valued their service-learning experiences. Although our results indicate that STEM literacy was enhanced by service-learning in the study projects, we have not been able to fully analyze the relationship between the service-learning and literacy outcomes.

\section{Acknowledgements}

The authors would like to thank Lisa Nelson, service-learning coordinator at Wayne State College, for her assistance and encouragement in this project. They would also like to thank Stacy DeVeau of ERAU for her assistance with this project.

\section{Author Note}

This research was partially funded by grants from Embry-Riddle Aeronautical University and service-learning at Wayne State College.

\section{Correspondence}

Barbara Hayford, Department of Life Sciences, Wayne State College, 1111 Main Street, Wayne, NE 68787; bahayfo1@wsc.edu

\section{References}

ACT. (2013). The condition of college and career readiness 2013. Retrieved from http://www.act.org/research/policymakers/cccr13/pdf/CCCR13-NationalReadinessRpt.pdf 
42 | International Journal of Research on Service-Learning and Community Engagement

Alberts, B. (2013). Prioritizing science education. Science, 340(6130), 249. doi:http://dx.doi.org/10.1126/science.1239041

Ammon, M. S., Furco, A., Chi, B., \& Middaugh, E. (2002). A profile of California's CalServe service-learning partnerships, 1997-2000. Sacramento, CA: California Department of Education.

Ash, S. L., \& Clayton, P. H. (2009). Generating, deepening, and documenting learning: The power of critical reflection in applied learning. Journal of Applied Learning in Higher Education, 1(1), $25-48$.

Astin, A.W., Vogelgesang, L.J., Ikeda, E.K., \& Yee, J. A. (2000). How service learning affects students. Los Angeles: Higher Education Research Institute, University of California.

Billig S. H. (2000). Research on K-12 school based service-learning: The evidence builds. Phi Delta Kappan, 81(9), 658-664.

Billig, S. H. (2002). Adoption, implementation, and sustainability of K-12 service-learning. Advances in Service-Learning Research, 1, 245-267.

Billig, S., \& Weah, W. (2008). K-12 service-learning standards for quality practice. Growing to Greatness, 6, 8-15.

Blomstrom, S. (2010). Identifying teaching effectiveness: Using student skill surveys, speech evaluations, and quiz scores to inform instruction. Communication and Theater Association of Minnesota, 37, 116-132.

Butin, D. W. (2006). The limits of service-learning in higher education. The Review of Higher Education, 29(4), 473-498.

Campus Compact. (2011). Initiatives: Service learning. Retrieved from http://www.compact.org/resources/service-learning_resources/in_engineering/

Eyler, J. (2002). Stretching to meet the challenge: Improving the quality of research to improve the quality of service-learning. Service-Learning Through a Multidisciplinary Lens (HC), 2, 1.

Eyler, J., \& Giles, D. E., Jr. (1999). Where's the learning in service-learning? San Francisco: JosseyBass.

Eyler, J., \& Giles, D. E., Jr. (1997). The importance of program quality in service-learning. In A. Waterman (Ed.), Service-learning: Applications from the research (pp. 57-76). Mahwah, NJ: Erlbaum.

Felton, P., \& Clayton, P. (2011) Service learning. New Directions in Teaching and Learning, 128, $75-84$.

Furco, A. (2002). Is service-learning really better than community service? In A. Furco \& S. Billig (Eds.), Service-learning: The essence of the pedagogy. Greenwich, CT: IAP.

Ghosh-Dastidar, U., \& Tsenova, P. (2012). Bio-math mapping: Water quality analysis of Hudson River and Gowanus Canal: A SENCER-based summer project. Science Education and Civic Engagement, 4(1), 55-65.

Hamann, H. B., \& Drossman, H. (2006). Integrating watershed management with learning: The role of information transfer in linking educators and students with community watershed partners. Comparative Technology Transfer and Society, 4(3), 305-337.

Holbrook, J., \& Rannikmae, M. (2009). The meaning of scientific literacy. International Journal of Environmental and Science Education, 4(3), 275-288.

Kammler, D. C., Truong, T. M., VanNess, G., \& McGowin, A. E. (2012). A service-learning project in chemistry: Environmental monitoring of a nature preserve. Journal of Chemical Education, 89(11), 1384-1389.

Kiely, R. (2005). A transformative learning model for service-learning: A longitudinal case study. Michigan Journal of Community Service Learning, 12, 5-22.

Kraft, R., \& Krug, J. (1994). Review of research and evaluation on service-learning in public and higher education. In R. Kraft \& M. Swadener (Eds.), Building community: Service learning in the academic disciplines (pp. 199-213). Denver, CO: Colorado Campus Compact. 
Krajcik, J. S., \& Sutherland, L. M. (2010). Supporting students in developing literacy in science. Science, 328(5977), 456-459. doi:http://dx.doi.org/10.1126/science.1182593

Laugksch, R. (2000). Scientific literacy: A conceptual overview. Science Education, 84, 71-94.

Learn and Serve America (2011). Service-learning definition, elements, and examples. Retrieved from http://www.learnandservearizona.com/\#Service-Learning\%20Standards

National Center for Educational Statistics. (2011). The nation's report card, science 2011. Retrieved from http://nces.ed.gov/nationsreportcard/pdf/main2011/2012465.pdf

Norris, S. P., \& Phillips, L. M. (2003). How literacy in its fundamental sense is central to scientific literacy. Science Education, 87, 224-240.

Pearson, P. D., Moje, E., \& Greenleaf, C. (2010). Literacy and science: Each in the service of the other. Science, 328(5977), 459-463.

Perry, J. L., \& Imperial, M. T. (2001). A decade of service-related research: A map of the field. Nonprofit and Voluntary Sector Quarterly, 30(3), 462-479.

Reynolds, J.A., \& Ahern-Dodson, J. (2010). Promoting science literacy through research servicelearning: An emerging pedagogy with significant benefits for students, faculty, universities, and communities. Journal of College Science Teaching, 39, 24-29.

Tedesco, L.P., \& Salazar, K.A. (2006). Using environmental service-learning in an urban environment to address water quality issues. Journal of Geoscience Education, 54, 123-132.

Yore, L. D., \& Treagust, D. F. (2006). Current realities and future possibilities: Language and science literacy - empowering research and informing instruction. International Journal of Science Education, 28(2-3), 291-314.

Yorio, P. L., \& Ye, F. (2012). A meta-analysis on the effects of service-learning on the social, personal, and cognitive outcomes of learning. Academy of Management Learning \& Education, 11(1), 9-27. 